\title{
Classification of Urban Parks and their Regional Characteristics in Dhaka City, Bangladesh
}

\author{
Saika Ummeh and Kikuchi Toshio \\ Department of Tourism Science, Tokyo Metropolitan University, Minami-Osawa, Hachioji-shi, Tokyo 192-0397, Japan
}

\begin{abstract}
Unplanned urbanization has caused serious ecological imbalances in Dhaka city. This study investigates the efficiency and utilization of urban green space especially parks of Dhaka city. The case study site covers urban parks of Dhaka metropolitan area of Bangladesh. Two aspects (physical and social) were applied for this study. For physical aspect, methods were used RS (Remote Sensing) and GIS (Geographic Information System) of three periods of images (Dhaka city). And for social aspect, methods were used questionnaire survey, observation, photographs, sketch and previous information about parks. After calculating all data result was showed by maps using GIS. For the changing pattern of green space of periods 1972, 1989 and 2010, result showed that the variation of the green space changes rate was high and gradually green space deceased and build up area increased in Dhaka city. Again according to physical size, parks of Dhaka city were classified into four types: Small, Medium, Large and Extra Large parks. Small parks of Dhaka city were situated beside the residential area and were used as daily purpose. Medium parks were located beside commercial area and its use was for daily and weekly. Large parks were placed at city center and only one extra large park was found outer range of city area. In large parks, people mainly visited monthly or occasionally. Moreover, the spatial-temporal changes of images showed the present status of green space of the city. The consequence of the study reveals that the utilization of park was controlled by various factors in Dhaka city.
\end{abstract}

Key words: Urban parks, Dhaka city, spatial-temporal change, classification of parks.

\section{Introduction}

The global population pressure has increased in urban areas with people thronging the cities in quest of a better life. According to the UN Population Division, about $44 \%$ of the total populations in developing countries are living in urban areas. There is no doubt that the urbanization will proceed to have significant impact on the ecology, economy and society at local, regional and global levels. The great impact has been observed in the urban green spaces including urban forestry, parks, playgrounds, domestic gardens, roadside open spaces and urban vegetation [1].

Apart from the benefit, they also support the construction of high-quality human settlements, since green spaces act as the "lungs" of the city [2].

Dhaka, the capital and the most populated city of Bangladesh, is now a member of the "mega-city"

Corresponding author: Saika Ummeh, Ph.D. student, research field: environmental geography. family of the world. Due to rapid and unplanned urbanization, commercial development, along with population pressure, the overall city environment is being worsened seriously day by day. But Dhaka city was once known for its serenity, beautiful parks, clean roads and lush greenery, various biodiversity and the places within the present Dhaka city boundary were forested, but at present those tree covers are almost transformed to urban habitats to accommodate excessive population due to high rate of rural-urban migration. In addition, industrialization in the urban fringe areas and transformation of different land use within the city as well as the surrounding urban fringes caused to the depletion of existing tree covers so rapidly during the last half century. The depletion process of green resources got impetus, as the government had no long term planning to keep city green except establishment of few parks and road side plantation under the city beautification programme. In some instances, 
government acted as the clearing agent of the greeneries. On the other hand, people in general are not properly aware of the importance of tree covers' existence in and around their living premises. Moreover, the absence of plantation process of trees in the past sites is also another important reason to remain the diminishing state of the existing tree cover in the city. Nowadays, very few green spots exist within city boundary as the reminiscence of past green glory [3].

As the city is, however, in a stage of transition, struggling with the challenges of urban expansion, over population, poverty alleviation and improving the quality of life and environment, all these facts raise the question about the future planning and managing strategies for green space in Dhaka city within multiple and rapidly changing urban demands and particularly, what opportunities exist for the development and what challenges should be overcome in the future for enhancing the overall urban green resource in and around Dhaka city.

\section{Literature Review}

\subsection{Definition and Importance of Urban Green Space}

Urban green spaces can be defined as outdoor places with significant amounts of vegetation, and exist mainly as semi-natural areas [4].

UGS (Urban Green Space) is defined as all publicly owned and publicly accessible open space with a high degree of cover by vegetation, e.g. parks, woodlands, nature areas and other green space [5].

Urban green space provides the following functions and objectives:

- Recreation and well-being;

- Aesthetics;

- Nature and landscape conservation;

- Biodiversity preservation;

- Climate and hygiene;

- Wood production;

- Food production [6].

\subsection{Urban Green Spaces as a Part of Urban Open} Spaces

Open space is any open part of land that is undeveloped (has no buildings or other built structures) and also accessible to the public. There are different types of open spaces. Such as:

- Green space (land that is partly or completely covered with grass, trees, shrubs, or other vegetation). Green space includes parks, community gardens, and cemeteries;

- Schoolyards;

- Playgrounds;

- Public seating areas;

- Public plazas;

- Vacant lots [7].

Again based on the nature of the land and the type of use, Nilufar [8] ordered all the public open spaces within Dhaka City under the following (Table 1) four categories.

Table 1 Type of open space in Dhaka city.

\begin{tabular}{|l|l|l|l|}
\hline Type of open space & Criteria & Example & Area \\
\hline Urban parks & Large open spaces & $\begin{array}{l}\text { Ramna park } \\
\text { Chandrima udyan } \\
\text { Osmani udyan } \\
\text { Sohrawardy udyan }\end{array}$ & $\begin{array}{l}50-80 \\
\text { acres }\end{array}$ \\
\hline $\begin{array}{l}\text { Urban recreational } \\
\text { areas }\end{array}$ & $\begin{array}{l}\text { Open spaces developed and assigned for more or } \\
\text { less organized outdoor recreational activities }\end{array}$ & $\begin{array}{l}\text { Stadiums and tennis Complex at metropolitan } \\
\text { scale, Armanitola play field at locale scale }\end{array}$ & $\begin{array}{l}2-9 \\
\text { acres }\end{array}$ \\
\hline $\begin{array}{l}\text { Urban development } \\
\text { open spaces }\end{array}$ & $\begin{array}{l}\text { Urban plazas/parks of various size in commercial } \\
\text { and institutional areas }\end{array}$ & $\begin{array}{l}\text { Pantha kunja } \\
\text { Anowara udyan } \\
\text { Gulistan park }\end{array}$ & $\begin{array}{l}2-8 \\
\text { acres }\end{array}$ \\
\hline $\begin{array}{l}\text { Functional } \\
\text { open spaces }\end{array}$ & Functional in nature & $\begin{array}{l}\text { Azimpur Graveyard, } \\
\text { Islambagh Eidgah Math }\end{array}$ & \\
\hline
\end{tabular}




\subsection{Changes of Green Space}

Luck and $\mathrm{Wu}$ [9] recognized that urbanization is one of the most important driving forces behind land-use and land-cover changes in Jinan City (China). Kong and Nakagoshi [10] reported that the driving forces are the policies that affect the development and management of urban green spaces. The causes of these changes in green spaces in the study area were also identified.

Again, Byomkesh, et al. [11] estimated that based on spatiotemporal green space dynamics, the green spaces of Greater Dhaka are rapidly decreasing. Estimates of green spaces using satellite images from 1975 to 2005 revealed that the rate of change in green spaces was consistently high, and in the last 30 years a total loss of 8617 ha was observed in comparison to the base year of 1975 .

\subsection{Importance of Park in Urban Life}

NRPA (National Recreation and Park Association) declared that parks and recreation have three values that make them essential services to communities: 1 . Economic value; 2. Health and environmental benefits; 3. Social importance [12].

Again, according to Casandra Campbell (Green Ribbon) eight reasons are important for Parks:

- Storm Water Collection;

- Reduction of the Urban Heat Island Effect;

- Centre of Community;

- Clean Air;

- Mental Health Boost;

- A Place for Physical Activity;

- A Place for Kids to Be Outside;

- Protect Natural Ecosystems [13].

Among the world's major cities, Greater Dhaka probably has the lowest number of playgrounds, parks, open spaces and swimming pools per capita [14].

Few studies have been conducted earlier on parks and green spaces. But, no organized study has been performed yet to evaluate the classification of parks in
Dhaka city considering multiple criteria and for improving the service area of urban parks. Therefore, in this research an attempt has been taken to classify all parks of Dhaka city with respect to their characteristics.

\section{Approaches of this Research}

The main objective of this research is to investigate the efficiency and utilization of urban green space especially parks of Dhaka city.

To achieve the research objective, two approaches are pointed out:

- To analyze the long term spatial and temporal changes of unban green space using with GIS (Geographical Information System), GPS (Global Positioning System) and RS (Remote Sensing) in Dhaka city;

- To identify classification of parks with their regional characteristics.

\section{Study Area}

Dhaka is the capital city of Bangladesh and it is located in the central part of the country.

Location: The location of Dhaka city is $23^{\circ} 41^{\prime}$ north latitude to $23^{\circ} 53^{\prime}$ north latitude and $90^{\circ} 21^{\prime}$ east longitude to $90^{\circ} 28^{\prime}$ east longitude.

Area: Dhaka Metropolitan Area 360 sq. km. Total area of Dhaka city corporation is 153.84 sq. km.

Administration: Dhaka is divided into two parts: DNCC (Dhaka North City Corporation) and DSCC (Dhaka South City Corporation) (Fig. 1). DNCC is situated in the northern part of the City which consists of 36 (Thirty Six) wards and the total area is about 82.638 sq. $\mathrm{km}$. And DSCC is situated in the southern part which consists of 57 wards and the total area is 71.202 sq. km.

\subsection{Green Space in Dhaka City}

Generally, the green areas within the Dhaka city and its periphery are broadly part of the open space (Fig. 2). 


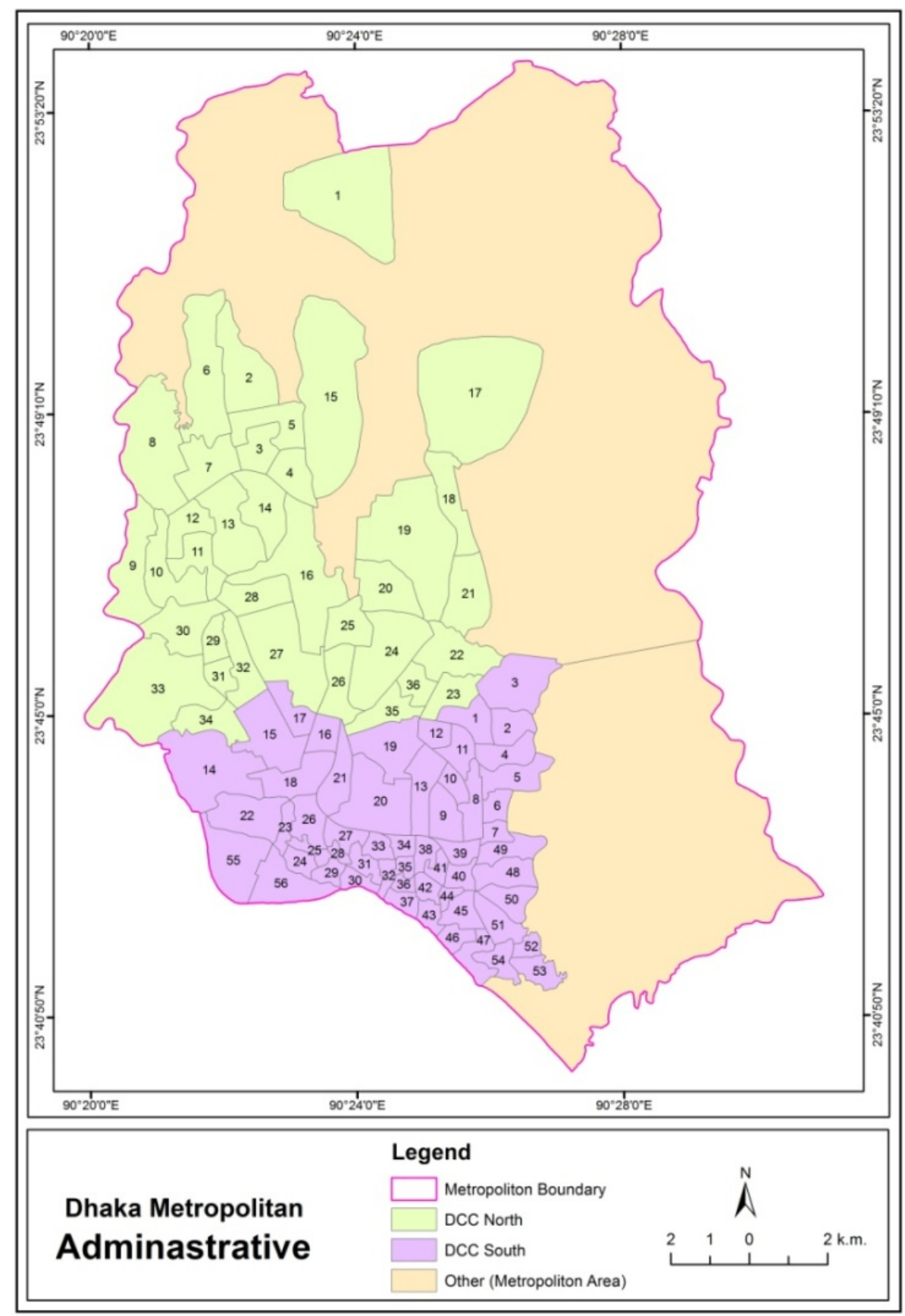

Fig. 1 Dhaka city.

According to the statistics of SDNPBD (Sustainable Development Networking Programme Bangladesh Department) 2005, the open space in Dhaka city is accounted only $21.573 \%$ of its total area [15]. As agriculture is the most dominant activity in Bangladesh, it comprises the highest proportion of open spaces that was about $12.12 \%$. That's why agriculture is not a part of green resources of Dhaka city. Thus, green resources in point of view of UPFG (Urban and Peri-Urban Forestry and Greening) in Dhaka city comprise:

- Trees along the streets, paved paths in commercial and residential areas, car parks etc.;

- Parks inside the town used for recreational purposes and generally consisting of different areas;

- Public and private Garden, graveyard, nursery, zoo, spots fields etc.; 


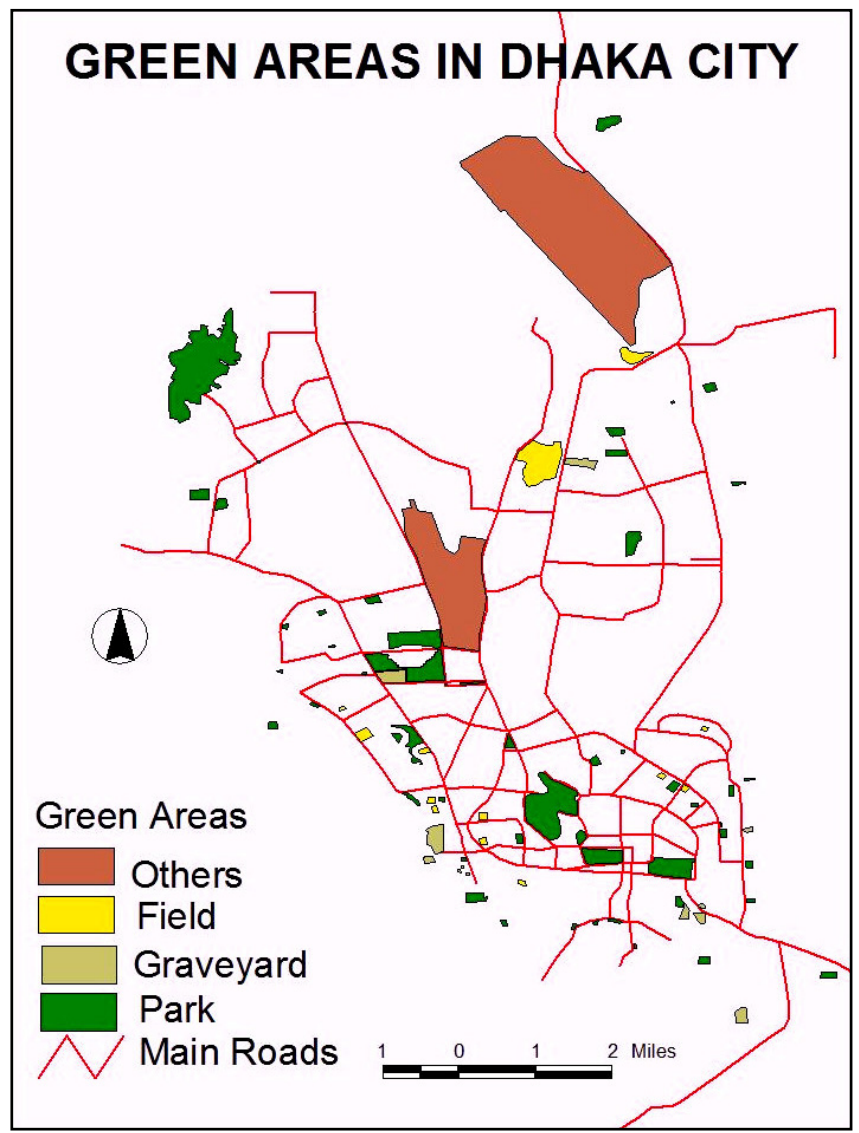

Fig. 2 Green areas in Dhaka city [16].

Table 2 Details of Landsat satellite image.

\begin{tabular}{llll}
\hline Respective year & $\begin{array}{l}\text { Date acquired } \\
\text { (Day/Month/Year) }\end{array}$ & Sensor & $\begin{array}{l}\text { Quality } \\
(100 \% \text { Cloud free) }\end{array}$ \\
\hline 1972 & $28-12-1972$ & Landsat 1 Multispectral Scanner (MSS) & 4 \\
1989 & $28-01-1989$ & Landsat 4-5 Thematic Mapper (TM) & 7 \\
2010 & $30-01-2010$ & Landsat 5 Thematic Mapper (TM) & 7 \\
\hline
\end{tabular}

- Other types of green areas may be within public or private areas;

- Larger green areas or National Parks outside the city but within the periphery, with some recreational use, mainly visited during holidays and weekends;

- Woodlots, social or community forest areas in peri-urban.

Therefore, green resources can be defined as trees or tree stands within the legal boundaries of DCC (Dhaka City Corporation) with the purpose of providing amenities for the population; namely shelter, recreation, landscaping, beauty etc. and additionally, both public and privately own large green areas, woodlots, social or community forest areas in the peri-urban areas of DCC for recreation and mostly timber, fuel wood and other products purposes [16].

\section{Methodology}

Two broad methods were used in this research. First, it was used of satellite images as secondary data source. To prepare the base maps for analysis purpose, Landsat satellite images (1972, 1989 and 2010) have been collected from the official website of USGS (U.S. Geological Survey). Table 2 shows the details of the Landsat satellite images used for analysis. 
For analysis, it needs to change all images for FCC (False Color Composite). These FCC images are useful to distinguish between different cover types or ground objects like buildings, roads and vegetation. After supervised classification of these images, for identifying the change of land cover of Dhaka city grid analysis were used.

Secondly, analysis of questionnaire survey of parks visitors, interviews with government authorities, field observations were carried out as primary data sources. The sample was selected randomly from the parks visitors and sample size was 400. This survey was done from October to November in 2015.

GIS has been used as a tool for mapping and represents present situation of green space of Dhaka city. Arc View GIS 3.3, Arc GIS 10.2, Erdas Imagine and other cartographic techniques were used.

\section{Spatial Analysis}

The extraction of green spaces along with other land-use classes from multi-temporal satellite data provided valuable information on the change of green spaces in Dhaka city during 1972-2010 (Table 3). This table clearly depicts how green spaces are disappearing in the study area over the course of time. Grid analysis showed a sizeable reduction in green spaces in the last 40 years. After analysis of classified change type (Table 4), it was found that most of the grid was transferred into built-up area than other land cover. On the other hand, in the eastern part of the city newly vegetated area (fellow land to vegetation) was also found. But overall city land covers intensively changed and the whole city was turned into buildup area.

\section{Classification and Characteristic of Parks}

How a park is defined may depend upon the perspective of the person identifying it. A park can be defined by its relationship to human or by its relationship to nature. In 1966, Charles Abrams defined park as an open area, usually landscape or left

Table 3 Spatial and temporal changes of land cover of Dhaka City.

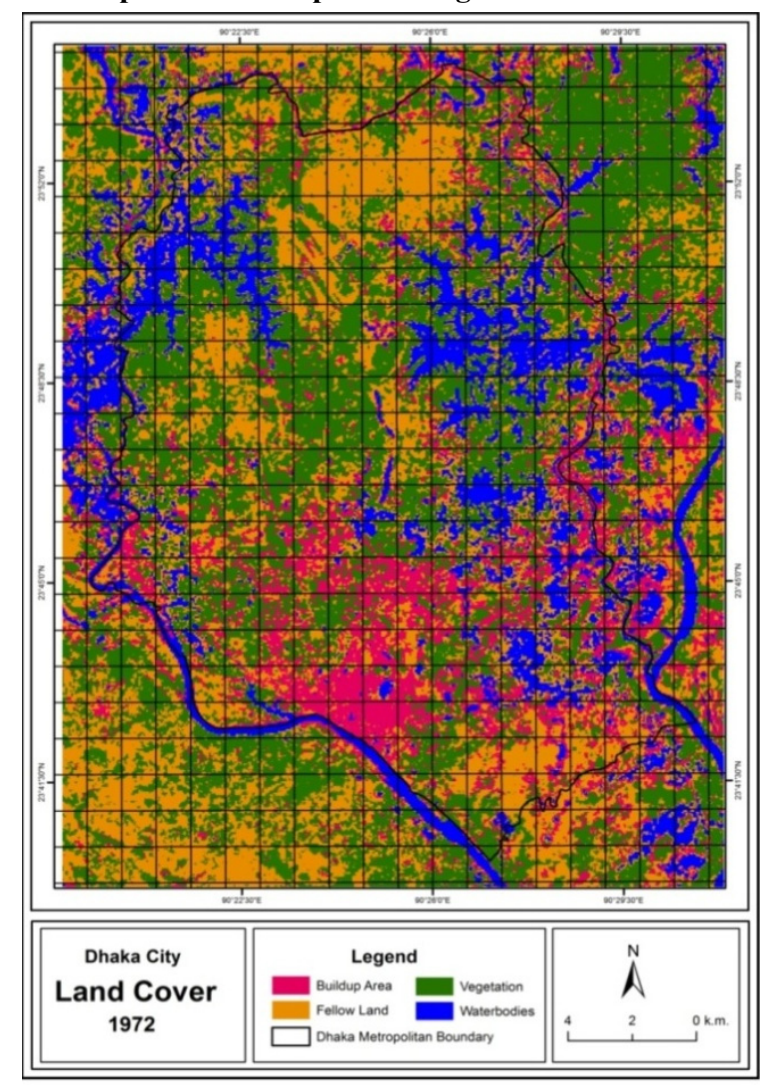

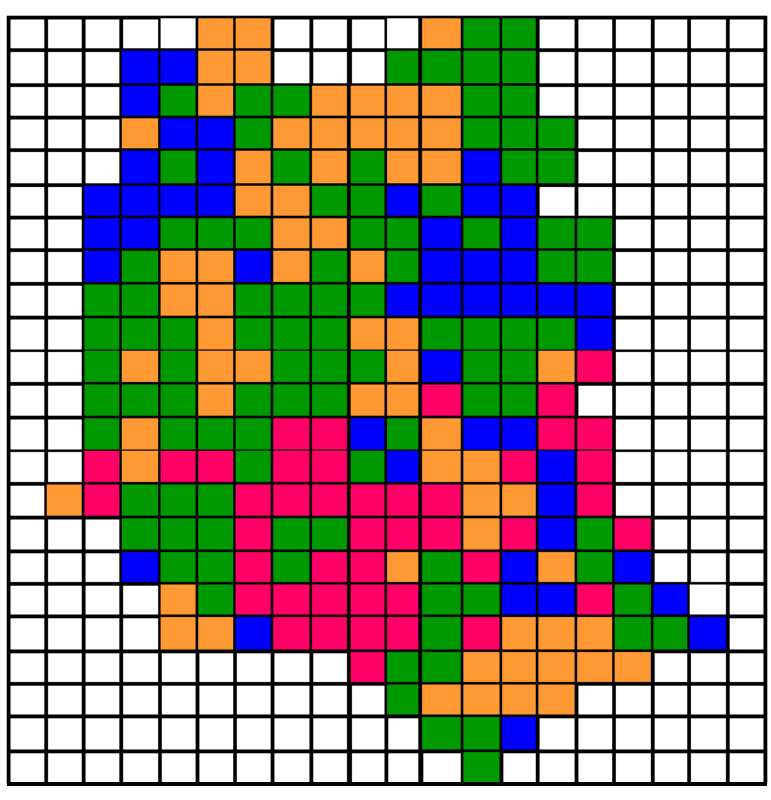

Grid analysis, Dhaka city (1972) 

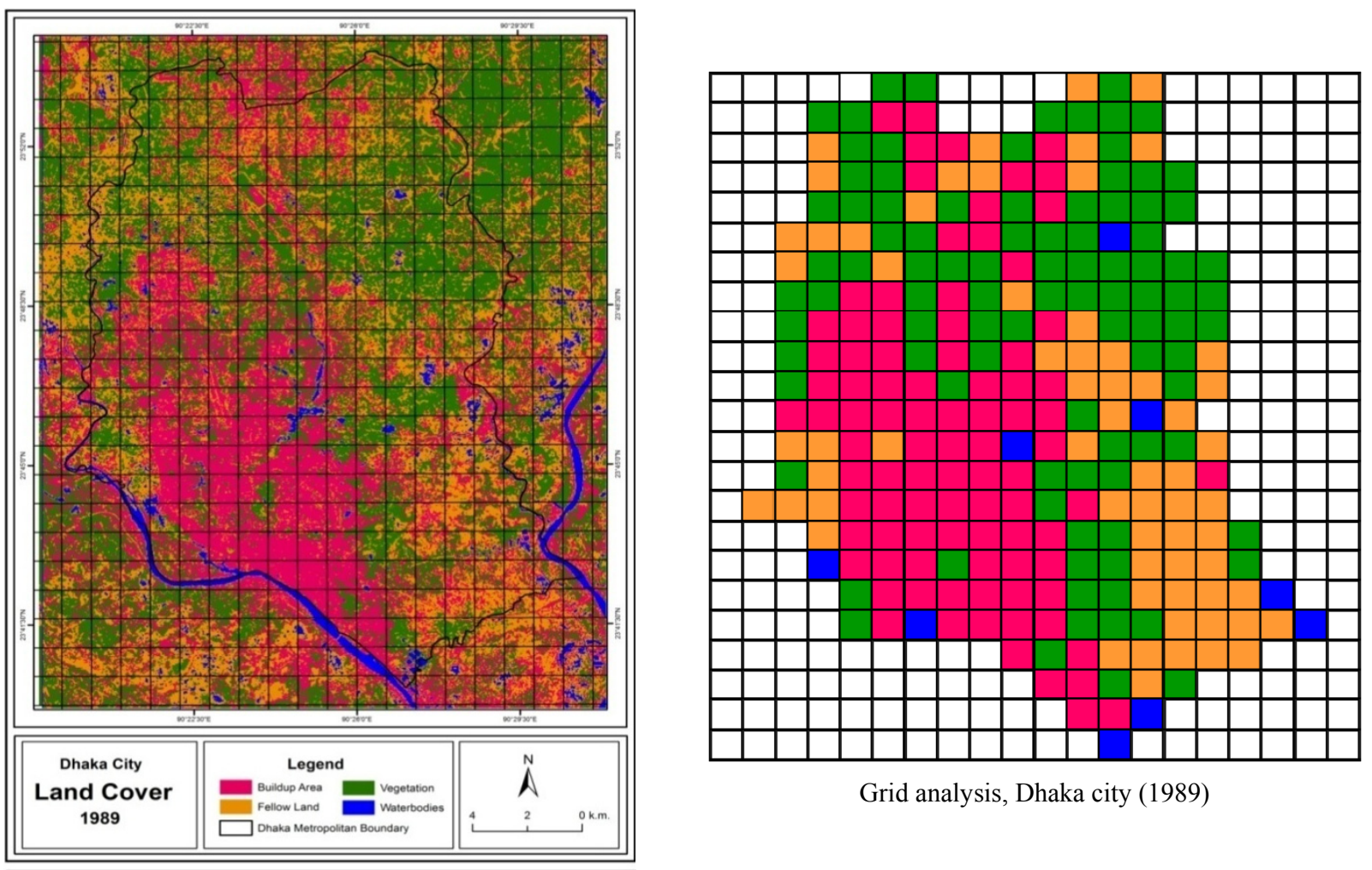

Grid analysis, Dhaka city (1989)
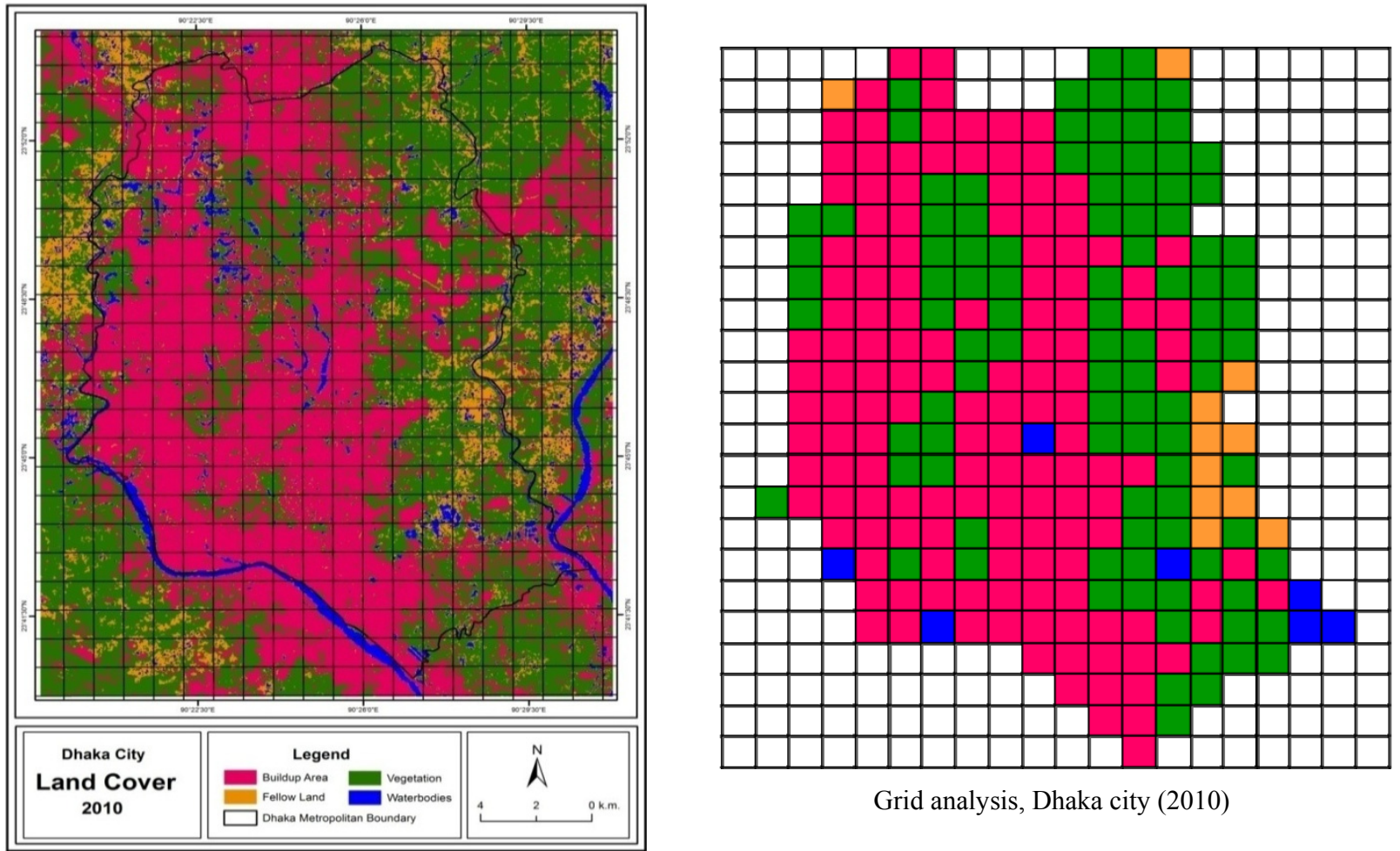

Grid analysis, Dhaka city (2010)

\begin{tabular}{|l|l|}
\hline Built-up area & All residential, commercial and industrial areas, infrastructure. \\
\hline Water body & River, permanent open water, lakes, ponds, canals and reservoirs. \\
\hline Vegetation & $\begin{array}{l}\text { Trees, shrub lands and semi natural vegetation, gardens, inner-city recreational areas, parks and } \\
\text { playgrounds, grassland and vegetable lands. }\end{array}$ \\
\hline Fallow land & $\begin{array}{l}\text { Fallow land, earth and sand land in-fillings, construction sites, developed land, excavation sites, solid } \\
\text { waste landfills, bare and exposed soils. }\end{array}$ \\
\hline
\end{tabular}


Table 4 Changes of land cover in Dhaka city by grid analysis.

\begin{tabular}{llll}
\hline Land cover 1989 & Land cover 1989 & Land cover 1989 & Grid number \\
\hline Fellow land & Buildup area & Buildup area & 18 \\
Vegetation & Buildup area & Buildup area & 30 \\
Fellow land & Fellow land & Buildup area & 27 \\
Vegetation & Vegetation & Buildup area & 20 \\
Water body & Vegetation & Buildup area & 15 \\
Buildup area & Buildup area & Buildup area & 28 \\
Fallow land & Vegetation & Vegetation & 11 \\
Vegetation & Vegetation & Vegetation & 24 \\
Vegetation & Fallow land & Vegetation & 18 \\
Fellow land & Fellow land & Vegetation & 15 \\
Others & & & 54 \\
Total & & & 260 \\
\hline
\end{tabular}

in its natural state, intended for outdoor recreation and the general enjoyment of nature [17]. At the same time, according to Rutledge parks were seen as natural area that served as passive retreats and recreation area that was focused on athletics and active facilities [18].

The parks are mainly classified into three ways: (a) according to their character; (b) according to their purpose; and (c) according to their size. All of them based on size it is more popular than the other classifications. Moreover, physical size of parks also describe detail characteristics of parks and easy to identify the service level of the urban area. In this research, parks of Dhaka city are classified based on their size.

According to NRPA, parks were classified into eight types based on their size [19]. Again, Rangwala 1974 classified parks based on the size into five types [20]. In 1984, according to Time-Saver Standard for Residential Development by Chiara, J. D. [21], the parks were classified into six types by size.

After all study, based on physical size, the parks of Dhaka city were classified into four types (Table 5).

Most of the parks of Dhaka city under the small size parks are scatteredly distributed. There are thirteen numbers of medium size parks which mostly distributed in north part of city and four large size parks in city center area. Again, only one extra large park is situated in the city boundary. After analysis of questionnaire data, based on these four categories of parks, regional characteristics of parks of Dhaka city are also identified (Table 6).

Small size parks of Dhaka city mainly are situated beside the residential area, medium size parks beside the commercial area, large size parks placed at city center and only one extra large size park found outer range of city area. Small parks mainly use as daily purpose. Medium parks use as daily and weekly. Again, in large parks people mainly visited monthly or occasionally and in extra large size park visit yearly. Moreover, small and medium size parks have good quantity of vegetated area but several social elements are absent (Table 7). Again, large size parks are used in various national occasion (Example: traditional fair, Bangla happy new year programe) more than the recreational purposes. In extra large size, parks are well organized and maintenance, and also all necessary social elements are present inside the park (Table 7).

\section{Urban Parks and their Service Area}

Basically, the service area of an urban green space covers the range of action where its potential users live and tends to border to the farthest user that has the availability to move to this space. This differs with the type of urban green space and the attractiveness and accessibility conditions. It is related to the measurement network depending on the attribute and criteria in question and has a more realist approach 
Table 5 Classification of parks in Dhaka city.

\begin{tabular}{lll}
\hline Type of park & Size & Number of parks \\
\hline Small & $0-4$ acres & 71 \\
Medium & $5-40$ acres & 13 \\
Large & $>40$ acres & 4 \\
Extra large & 200 acres + & 1 \\
\hline
\end{tabular}

Table 6 Regional characteristics of parks in Dhaka city.

\begin{tabular}{|l|l|l|l|l|}
\hline Factors & Small size park & Medium size park & Large size park & Extra large size park \\
\hline Area (Acres) & Less than 4 & $4-40$ & Greater than 40 & $200+$ \\
\hline Shape & Round or Square & Rectangular & Irregular & Irregular \\
\hline Radius of serve area & Quarter-mile & Half-mile & Two-miles & Entire city \\
\hline Located & Beside the residential area & $\begin{array}{l}\text { Beside the institutional or } \\
\text { commercial area }\end{array}$ & City center & City boundary \\
\hline Vegetated area & High and mixed wood & High wood and Grass land & $\begin{array}{l}\text { High, low and mixed } \\
\text { wood }\end{array}$ & $\begin{array}{l}\text { High, low, mixed wood } \\
\text { and also Nursery }\end{array}$ \\
\hline Non-vegetated area & Open Space & $\begin{array}{l}\text { Open space, sometime } \\
\text { water bodies }\end{array}$ & $\begin{array}{l}\text { Open space and water } \\
\text { bodies }\end{array}$ & $\begin{array}{l}\text { Open space and water } \\
\text { bodies }\end{array}$ \\
\hline Recreation activities & $\begin{array}{l}\text { Mainly Active, sometime } \\
\text { Passive }\end{array}$ & Active and Passive & $\begin{array}{l}\text { Mainly Passive, sometime } \\
\text { Active }\end{array}$ & Outdoor \\
\hline Purposes of visitor & Physical exercise & $\begin{array}{l}\text { Physical exercise and } \\
\text { leisure period }\end{array}$ & $\begin{array}{l}\text { Cultural programme, } \\
\text { Festivals, various occasion }\end{array}$ & $\begin{array}{l}\text { Picnic, site seeing, whole } \\
\text { day spending }\end{array}$ \\
\hline Frequency of use & Daily & Daily to weekly & Monthly & Yearly \\
\hline Transport facilities & Walking & $\begin{array}{l}\text { Walking, private vehicles, } \\
\text { auto rickshaw }\end{array}$ & $\begin{array}{l}\text { Vehicle (Private and } \\
\text { hiring) }\end{array}$ & $\begin{array}{l}\text { Bus, Vehicle (Private and } \\
\text { hiring) }\end{array}$ \\
\hline
\end{tabular}

Table 7 Physical and social elements of parks in Dhaka city.

\begin{tabular}{|c|c|c|c|c|}
\hline \multirow[t]{4}{*}{ Elements } & Small size park & Medium size park & Large size park & Extra large size park \\
\hline & Physical elements & & & \\
\hline & Flower trees & Flower and fruit trees & Flower, fruit and bamboo trees & $\begin{array}{l}\text { Flower, fruit, bamboo and } \\
\text { other foreign species }\end{array}$ \\
\hline & $\underline{\text { Social elements }}$ & & & \\
\hline Gate & & & & \\
\hline Bench-Table & & & & \\
\hline Dustbin & & & & \\
\hline Toilet & & & & \\
\hline Medical facilities & & & & \\
\hline Sport field & & & & \\
\hline Children zone & & & & \\
\hline Food corner & & & & \\
\hline Parking & & & & \\
\hline Sport field & & & & \\
\hline Water bodies & & & & \\
\hline Orchid house & & & & \\
\hline Watch tower & & & & \\
\hline Picnic area & & & & \\
\hline Research center & & & & \\
\hline Bridge & & & & \\
\hline Rest house & & & & \\
\hline Present & & & & \\
\hline Absent & & & & \\
\hline
\end{tabular}


compared to buffer approach (linear distance) because it has accounted the multiple limitations that influence the network dynamics. The concept can also be applied to a public equipment or service that has a territorial expression [22].

For an urban park, it is very essential to identify the service area. Service area of a park means the particular range of area where population can be used the park facilities. It mainly depends on the size and the accessibility of the parks. In this research, it used the buffer approach of each park to show the service area.

The maps on Table 8 illustrate the service areas for small, medium, large and extra large parks of Dhaka city. Service areas are consistent with the guidelines established by the NRPA (Fig. 3). The special use parks and facilities do not have defined service areas as they are considered to offer amenities and services that appeal to the entire resident population of the urban area. In some cases, the actual service area of any park may be larger if the park includes amenities of regional appeal. Smaller service areas are also possible where major roadways act as barriers to park access. For illustration purposes, these roadway barriers are not shown.

\section{Findings and Conclusion}

Parks are one aspect of urban environment which is great importance in daily life as well as social life for people who live in urban areas like Dhaka. At dense urban area parks should be the most vibrant and accessible space. But somehow, their importance is often forgotten in the debate about architecture and built form.

In Dhaka, rapid growth of urban population has caused the huge encroachment of green space due to increasing demand on land for housing and other urbanization need. As a result, built-up area increases very rapidly within last 40 years. And most of the land covers transfer into built-up area. These changes influence urban environment both socially and naturally. So it's essential to classify the parks (source of green space) and also identify the regional characteristic of parks for their better utilization.

Again, after analysis it is found that size of parks and accessibility are interrelated (Fig. 4). In small size parks people visit daily purpose and their accessibility level is high. In medium size parks, people visit daily to weekly and accessibility is moderate. Moreover, in large size park people visit occasionally signify once a month and accessibility level is moderate. And in extra large parks people visit yearly as for whole day staying and accessibility level is low in here.

Once more, from the analysis of service area it shows that small and medium size parks cannot serve

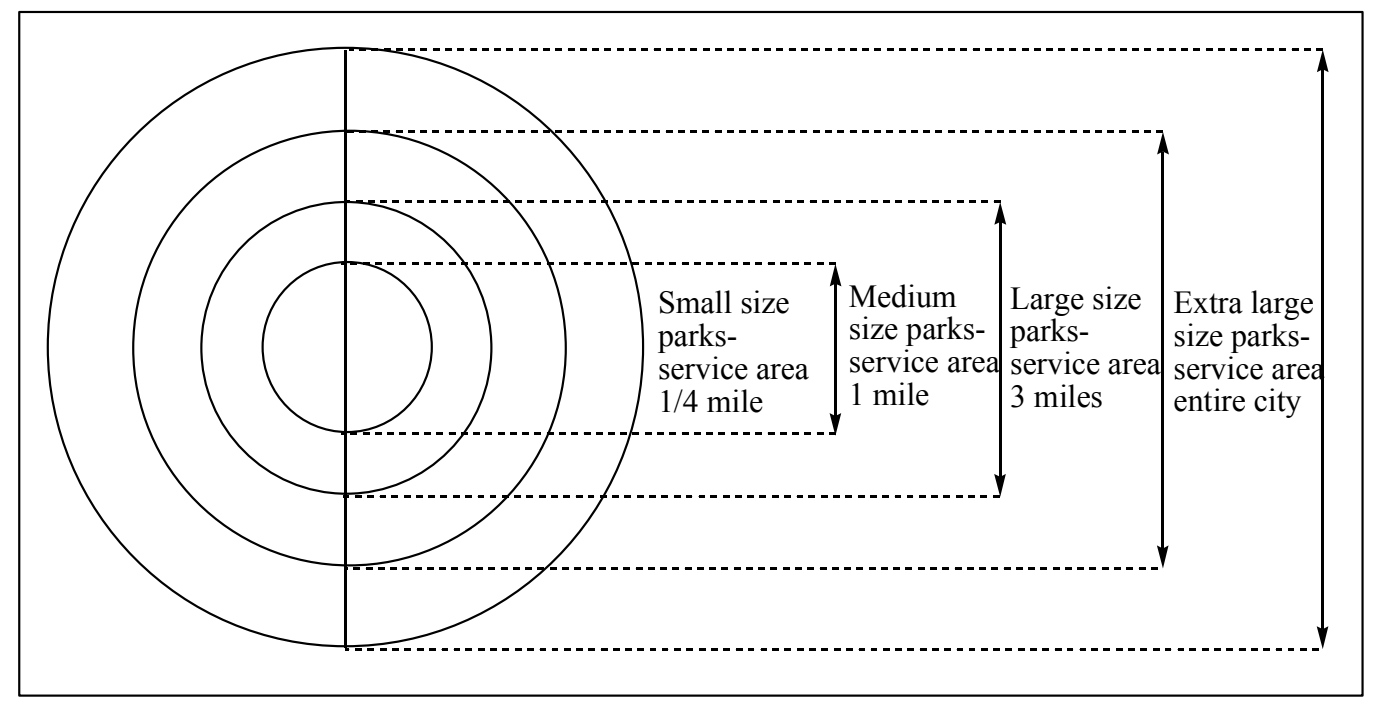

Fig. 3 Range of service area of different size parks. 
Table 8 Service area of parks in Dhaka city.

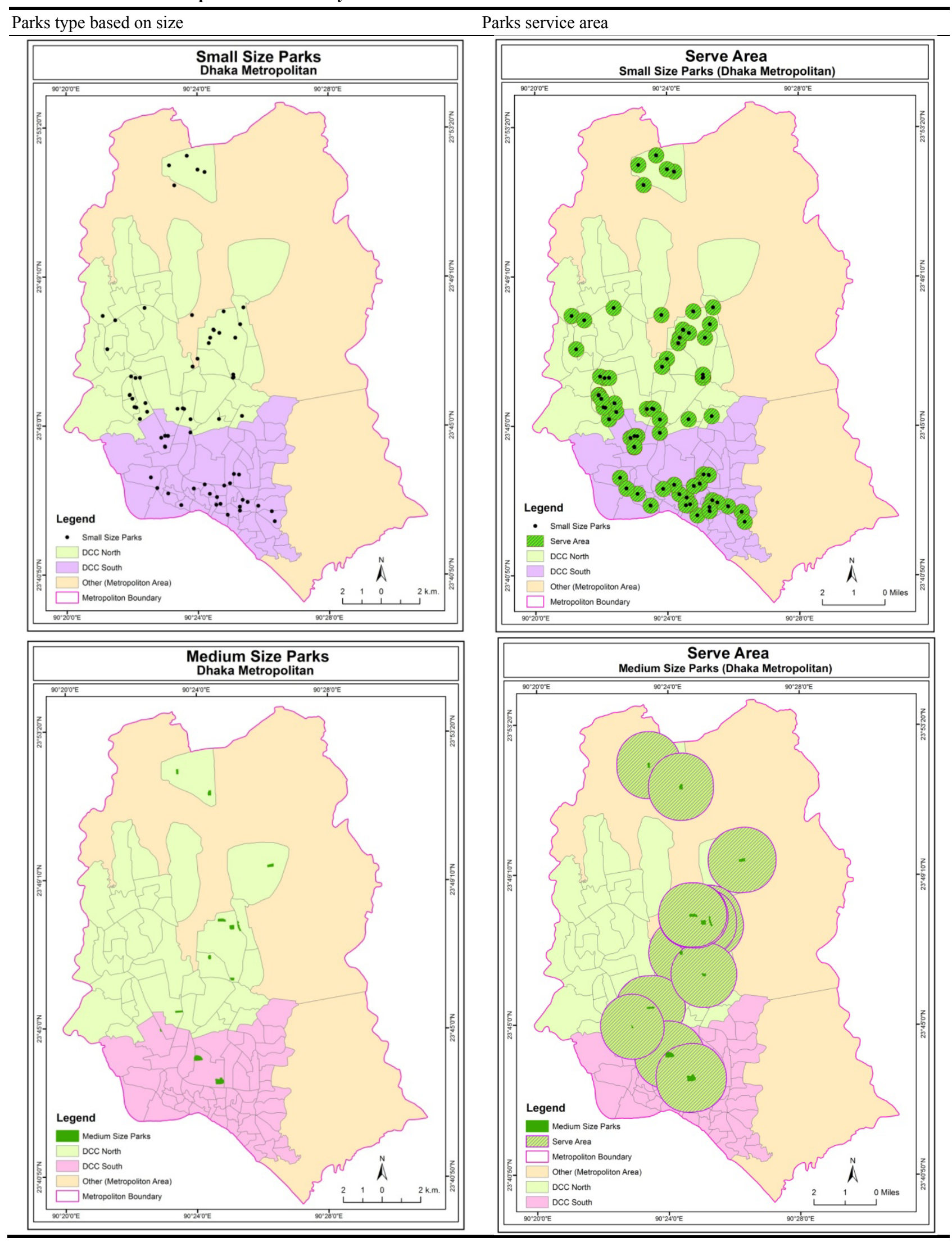



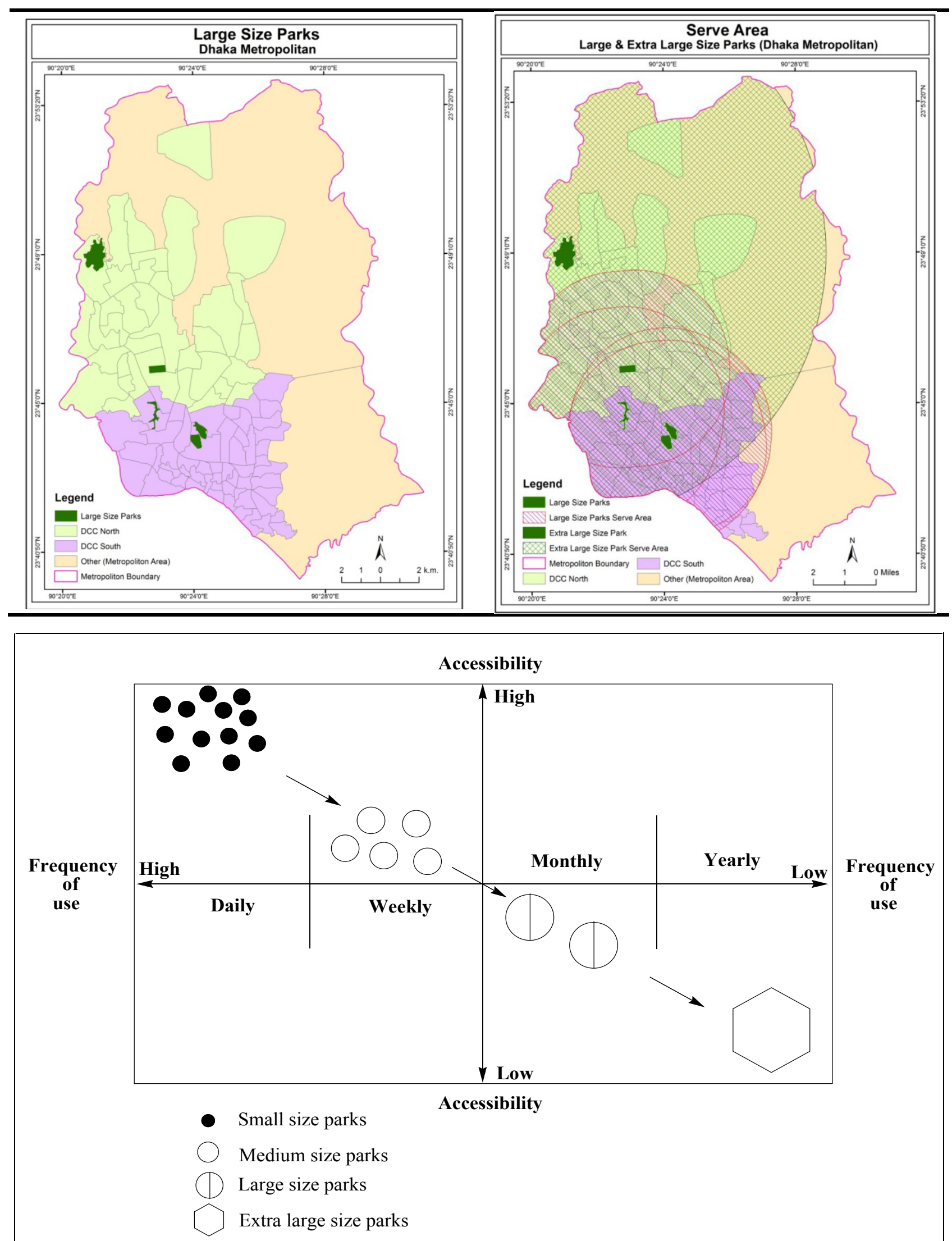

Fig. 4 Relationship between size of parks and accessibility. 
the city equally but accessibility is high in here. Again, in large size parks mainly serve the city center area and other part of the city also deprived. Moreover, extra large size park serve the whole city but in here accessibility is low.

Urban parks are very essential element for meeting the recreational need in the urban population. In the Dhaka city, it is almost impossible to create a new park for high land price and inadequate land. Hence, it should be taken care of the existing parks but existing green spaces face various weaknesses in management due to lack of awareness, maintenance and management. For this reason, there is need for effective management of existing parks. For proper management of green space strong coordination among different organizations is mandatory.

\section{Acknowledgement}

This work is supported by priority research program sponsored by the Asian Human Resources Fund of TMG (Tokyo Metropolitan Government).

\section{References}

[1] Rahman, M. Z., and Siddiquee, S. A. 2012. "Urban Forestry for Green City." Accessed September 22, 2012. http://archive.thedailystar.net/newDesign/news-details.ph p?nid $=250707$.

[2] Jim, C. Y., and Chen, W. Y. 2006. "Perception and Attitude of Residents toward Urban Green Spaces in Guangzhou (China).” Environmental Management 38 (3): 338-49.

[3] Islam, S. T. 2002. "Greening and Fading the Dhaka City: Past, Present and Future Perspectives." Unpublished Project Report. The Asiatic Society of Bangladesh, Dhaka. Bangladesh.

[4] Jim, C. Y., and Chen, S. S. 2003. "Comprehensive Greenspace Planning Based on Landscape Ecology Principles in Compact Nanjing City, China." Landscape and Urban Planning 65 (3): 95-116.

[5] Schipperijn, J., Stigsdotter, U. K., Randrup, T. B., and Troelsen, J. 2010. "Influences on the Use of Urban Green Space-A Case Study in Odense, Denmark." Urban Forestry and Urban Greening 9 (1): 25-32.

[6] Chiari, C. G., and Seeland, K. 2004. "Are Urban Spaces Optimally Distributed to Act as Places for Social Integration? Result of a Geographical Information
System (GIS) Approach for Urban Forestry Research." Forest Policy and Economics 6 (1): 3-13.

[7] United States Environmental Protection Agency (EPA). 2014. "What is Open Space/Green Space?" Accessed November 23, 2014. http://www.epa.gov/region1/eco/uep/openspace.html.

[8] Nilufar, F. 1999. "Urban Life and Public Open Space in Dhaka." Report submitted to Asiatic Society of Bangladesh, Dhaka. Bangladesh.

[9] Luck, M., and Wu, J. 2002. "A Gradient Analysis of Urban Landscape Pattern: A Case Study from the Phoenix Metropolitan Region, Arizona, USA." Landscape Ecology 17 (4): 327-39.

[10] Kong, F., and Nakagoshi, N. 2006. "Spatial-Temporal Gradient Analysis of Urban Green Spaces in Jinan, China." Landscape and Urban Planning 78 (3): 147-64.

[11] Byomkesh, T., Nakagoshi, N., and Dewan, A. M. 2012. "Urbanization and Green Space Dynamics in Greater Dhaka, Bangladesh." Landscape and Ecological Engineering 8 (1): 45-58.

[12] National Recreation and Park Association (NRPA). 2010. "Why Parks and Recreation are Essential Public Services." Accessed January 15, 2010. https://www.nrpa.org/uploadedFiles/nrpa.org/Advocacy/ Resources/Parks-Recreation-Essential-Public-Services-Ja nuary-2010.pdf.

[13] Casandra, C. 2016. "8 Reasons Why Parks are Important." Accessed Jun 10, 2016. http://www.gardinergreenribbon. com/why-parks-are-important./.

[14] Hossain, S. 2006. "Social Characteristics of a Megacity: A Case of Dhaka City, Bangladesh.” Proc TASA 2006 Conf, Perth, Australia: 4-7.

[15] Sustainable Development Networking Programme Bangladesh Department (SDNPBD). 2005. "Green Cities Plan for the Planet (Digital Publication)." World Environment Day 2005. Dhaka. Bangladesh.

[16] Ansari, M. N. A. 2008. "Opportunities and Challenges of Urban and Peri-urban Forestry and Greening in Bangladesh: Dhaka City as a Case." Master's Thesis, Department of Landscape Management, Design and Construction, Swedish University of Agricultural Sciences (SLU), Alnarp, Sweden.

[17] Abrams, C. 1967. The City is the Frontier. Washington: The National Academies of Sciences, Engineering, and Medicine.

[18] District of Saanich. 2016. "Rutledge Parks - Possible Splash Pad and Washroom Building." Accessed May 25, 2016. http://www.saanich.ca/EN/main/parks-recreation-culture/ parks/projects-in-saanich-parks/active-projects/rutledge-p ark.html.

[19] National Recreation and Park Association (NRPA). 2014. 
"Dallas Parks and Recreation." Accessed April 22, 2014. http://www.dallasparks.org/151/Park-Classifications.

[20] Rangwala, S. C., Rangwala, K. S., and Rangwala, P. S. 2003. Town Planning 18th ed. Charotar Publishing House PVT. LTD. Anan 388001 Gujarat, India.

[21] De Chiara, J., and Koppelman, L. 1975. Urban Planning and Design Criteria, 2nd Edition. New York: Van
Nostrand Reinhold Company.

[22] Figueiredo, R. 2016. "Service Areas of Local Urban Green Spaces: An Explorative Approach in Arroios, Lisbon.” Instituto Superior Técnico, University of Lisbon. Accessed September 2016. https://fenix.tecnico.ulisboa.pt/downloadFile/5633450904 13116/resumo.pdf. 